\title{
MANAJEMEN PRODUKSI DAN KOMUNIKASI PROGRAM KOMEDI BAELANG (Studi Kasus di LPP TVRI Kalimantan Timur)
}

\author{
Fredy Masahengke \\ E-mail :fredymasahengke7@gmail.com
}

Lembaga Penyiaran Publik Televisi Republik Indonesia Stasiun Kaltim

\begin{abstract}
This research shows the role of management, communication and producer in the production of television programs, especially the comedy program Baelang in planning, organizing, implementing and evaluating and organizing the production of Comedy Baelang program in TVRI East Kalimantan. This research is qualitative and the data obtained in accordance with the subjects and research objects. The research was conducted by direct involvement method, observation and interview which was done unstructured in informal atmosphere.
\end{abstract}

Keywords: Management, Communication and Producer

\section{PENDAHULUAN}

Penyiaran televisi merupakan produksi dan siaran televisi yang diselenggarakan oleh suatu lembaga televisi.Hasil atau keluaran dari produk organisasi penyiaran televisi adalah siaran televisi yang ditujukan kepada khalayak melalui penerimaan pesawat televisi. Proses penyelenggaraan siaran televisi merupakan proses yang relative panjang dan rumit berdasarkan pola pikir dan pola tindak yang dinamis, praktis, cepat, tepat dan berkualitas. Hal ini mengharuskan manajemen yang diterapkan dalam setiap proses produksi dan penyelenggaraan siaran harus dinamis. Siaran televisi berkaitan dengan penerapan fungsifungsi manajemen yang dilakukan setiap Bidang dalam organisasi di LPP TVRI Kalimantan Timur. 
Salah satu program acara Pengarahan (directing) dan yang diproduksi oleh LPP TVRI Pengawasan (controlling) serta Kalimantan Timuradalah program Komunikasi dalam program Komedi lawak / komedi Baelang. Program Baelang di LPP TVRI Kalimantan acara ini diproduksi distudio (video Timur, 2.Untuk mengetahui taping) dengan sistim siaran bagaiman strategi Komunikasi tunda.Beberapa permasalahan yang Produser dalam mengelola program dihadapi diantaranya: pencarian komedi Baelang di LPP TVRI pengisi acara yang berkualitas, Kalimantan Timur, 3.Untuk penjadwalan, sarana penunjang, mengetahui apa saja kendala yang sumber daya manusia fungsional, dihadapi kerabat kerja dalam komunikasi, evaluasi program, pelaksanaan produksi distudio (video menurut Penulis permasalahan di taping) serta saat penyiaran program atas berkaitan dengan persoalan Komedi Baelang di LPP TVRI manajemen dan komunikasi. Kalimantan Timur.

Berdasarkan latar belakang di atas maka penulis membuat pembatasan masalah dalam penelitian ini yaitu "Manajemen Produksi dan Komunikasi Program Komedi Baelang" berdasarkan studi kasus di LPP TVRI Kalimantan Timur.Tujuan penelitian ini adalah: 1.Untuk mengetahui bagaimana implementasi fungsi-fungsi manajemen yaitu Perencanaan (planning), Pengorganisasian (organizing),

\section{TINJAUAN TEORITIS}

Morissan (2013:138), Manajer Umum pada dasarnya bertanggung jawab dalam setiap aspek organisasi suatu stasiun penyiaran. Dalam melaksanakan tanggung jawab empat fungsi dasar yaitu : Perencanaan (planning), Pengorganisasian (planning), Pengarahan dan memberikan pengaruh (directing),Pengawasan 
(controlling). M.George R. Terry yang di alibahasakan oleh G. A. Ticoalu (2015:1) :“Manajemen adalah suatu proses yang membedakan atas perencanaan, pengorganisasian, penggerakan pelaksanaan dan pengawasan dengan memanfaatkan baik ilmu maupun seni agar dapat menyelesaikan tujuan yang telah ditetapkan sebelumnya. Menurut Rusman Latif dan Yusiatie Utud (2015:145-146),"Untuk memproduksi program televisi ada standar kerja yang disebut dengan Standard Operational Proscedur (SOP) berfungsi sebagai acuan dalam tahapan proses produksi, yaitu praproduksi, produksi, dan paskaproduksi."

Strategi komunikasi Menurur Yusuf Zainal Abidin (2015:115) "adalah perencanaan (planning) dan manajemen (management) untuk mencapai satu tujuan.Untuk mencapai tujuan tersebut, strategi tidak berfungsi sebagai peta jalan yang hanya menunjukkan arah, tetapi juga harus menunjukkan taktik operasionalnya". Menurut Onong Uchjana Effendy "Strategi komunikasi merupakan paduan dari perencanaan komunikasi dan manajemen komunikasi untuk mencapai tujuan yang telah ditetapkan. Strategi komunikasi harus mampu menunjukkan operasionalnya secara praktis, artinya pendekatan yang digunakan dapat berbeda bergantung pada situasi dan kondisi."

Pada penelitian ini, hanya fokus pada upaya manajemen pada tiga unsur komunikasi,yakni komunikator, media,dan pesan. Adapun fungsi manajemen yang digunakan adalah peren-canaan, pengorganisasian, pelak-sanaan dan pengendalian.Pertemuan antara fungsi manajemen dan unsur komunikasi dapat digambarkan seperti di bawah ini: 


\begin{tabular}{|c|c|c|c|}
\hline Manajemen & Komunikator & Media & Pesan \\
\hline Perencanaan & $\begin{array}{l}\text { Perencanaan } \\
\text { Komunikator }\end{array}$ & Perencanaan Media & Perencanaan Pesan \\
\hline Pengorganisasian & $\begin{array}{c}\text { Pengorganisasian } \\
\text { Komunikator }\end{array}$ & $\begin{array}{c}\text { Pengorganisasian } \\
\text { Media }\end{array}$ & $\begin{array}{c}\text { Pengorganisasian } \\
\text { Pesan } \\
\end{array}$ \\
\hline Pelaksanaan & $\begin{array}{l}\text { Pelaksanaan } \\
\text { Komunikator }\end{array}$ & Pelaksanaan Media & Pelaksanaan Pesan \\
\hline Pengendalian & $\begin{array}{l}\text { Pengendalian } \\
\text { Komunikator }\end{array}$ & $\begin{array}{c}\text { Pengendalian } \\
\text { Media }\end{array}$ & Pengendalian Pesan \\
\hline
\end{tabular}

Penelitian ini menggunakan metode deskriptif kualitatif, artinya hanya memaparkan situasi atau peristiwa yang terjadi, sacara jelas, terperinci, dan sesuai dengan fakta yang ada.

\section{PEMBAHASAN}

A. Analisis implementasi fungsifungsi manajemen serta komunikasi dalam produksi program Komedi Baelang di LPP TVRI Kalimantan Timur

Manajemen adalah suatu proses atau kerangka kerja, yang melibatkan bimbingan atau pengarahan suatu kelompok orangorang kearah tujuan-tujuan organisasi atau maksud-masud yang nyata (George R. Terry dan Leslie W. Rue. 2015:1). Pada hakekatnya manajemen sangat penting dan dibutuhkan dalam kehidupan, terlebih dalam sebuah instansi, organisasi hingga perusahaan. Karena pada dasarnya manajemen adalah sebuah proses untuk membentuk aturan dan kendali dalam tubuh struktur organisasi tersebut.

Rois Arifin dan Helmi Muhammad (2016:2) “Manajemen adalah seni dalam menyelesaikan pekerjaan melalui orang lain". Definisi ini mengandung arti bahwa para manajer akan mencapai tujuantujuan organisasi dengan mengatur orang-orang lain untuk melaksanakan berbagi tugas yang diperlukan. Manajemen mempunyai pengertian yang lebih luas, sehingga dalam kenyataannya tidak ada 
definisi yang digunakan secra konsisten oleh semua orang.

$$
\text { Manajemen penyiaran }
$$

menurut JB.Wahyudi

“adalah manajemen yang diterapkan dalam organisasi penyiaran, yaitu organisasi yang mengelola siaran, manejemen penyiaran sebagai motor penggerak organisasi penyiaran dalam usaha pencapaian tujuan bersama melalui penyelenggaraan siaran". Para pengelola manajemen penyiaran, harus menguasai ilmu manajemen dan ilmu komunikasi, termasuk didalamnya penyelenggaraan siaran sebagai salah satu bentuk proses komunikasi massa.

Mengelola media penyiaran pada dasarnya adalah mengelola manusia.Menurut Morissan (2013:133) “Keberhasilan media penyiaran sejatinya ditopang oleh kreativitas manusia yang bekerja pada tiga pilar utama yang merupakan fungsi vital yang dimiliki setiap media penyiaran yaitu teknik, program, dan pemasaran". Keberhasilan TVRI Kalimantan Timur bergantung pada bagaimana kualitas orang-orang yang bekerja pada tiga bidang tersebut. Namun demikian, kualitas manusia saja tidak cukup jika tidak disertai dengan kemampuan pimpinan TVRI Kalimantan Timur dalammengelola sumber daya manusia yang ada.

Banyak tantangan yang dihadapi dalam mengelola media penyiaran menurut Peter Pringle di dalam Morissan (2013:134) “Tidak banyak posisi manajemen yang memberikan tantangan yang setara dengan mengelola suatu stasiun radio dan televisi lokal". Lebih lanjut Morissan (2013: 133-169) tantangan yang harus dihadapi manajemen media penyiaran disebabkan oleh dua hal.

Pertama: sebagaimana perusahan lainnya, media penyiaran dalam kegiatan operasionalnya harus dapat memenuhi harapan pemilik dan pemegang saham untuk 
menjadi perusahaan yang sehat dan mampu menghasilkan keuntungan.

Dalam hal ini TVRI Kalimantan Timur diharapkan mampu memenuhi harapan pemerintah untuk menjadi televisi publik yang sehat dan tidak berorientasi mencari keuntungan, tetapi lebih pada melayani masyarakat dan sebagi media untuk menginformasikan keberhasilan pembangunan dan menjaga keutuhan berbangsa dan bernegara.

Sebagai tantangan kedua: media penyiaran harus mampu memenuhi kepentingan masyarakat (komunitas) dimana media bersangkutan berada, sebagai ketentuan yang harus dipenuhi ketika media penyiaran bersangkutan menerima izin siaran (lisensi) yang diberikan negara. Dalam tantangan kedua ini TVRI Kalimantan Timur sebagai media penyiaran publik di Kalimantan Timur dan Kalimantan utara mempunyai tugas ( Pasal 4 PP No.
13 Tahun 2005) memberikan pelayanan informasi, pendidikan, hiburan yang sehat, control dan perekat sosial, serta melestarikan budaya bangsa untuk kepentingan seluruh lapisan masyarakat melalui penyelenggaraan penyiaran televisi yang menjangkau seluruh wilayah Negara Kesatuan Republik Indonesia. Khusus untuk TVRI Kaltim jangkauan siaran diharapkan meliputi daerah Kalimantan Timur dan Kalimantan Utara.

Pada dasarnya manajemen dibutuhkan oleh semua organisasi karena tanpa manajemen semua usaha akan sia-sia dan pencapaian tujuan akan menjadi lebih sulit. Menurut Morissan (2013:135) "Ada tiga alasan utama bahwa manajemen diperlukan untuk mencapai tujuan, untuk menjaga keseimbangan dan untuk mencapai efisiensi dan efektivitas". Terkait alasan tersebut maka TVRI Kalimantan Timur menggunakan manajemen: 
1) Untuk mencapai tujuan. TVRI Kalimantan Timur menggunakan manajemen untuk mencapai tujuan dalam hal produksi program Komedi Baelang.

2) Untuk menjaga keseimbangan. Manajemen dibutuhkan untuk menjaga keseimbangan antara tujuan-tujuan, sasaran-sasaran dan kegiatan-kegiatan yang saling bertentangan dari pihakpihak yang berkepentingan dalam organisasi. Terkait hal tersebut maka program Komedi Baelang merupakan salah satu hasil dari kebijakan jajaran manajemen TVRI Kalimantan Timur guna mencapai keseimbangan program acara yaitu program berita dan informasi dengan program acara yang bersifat hiburan seperti Komedi Baelang.

3) Untuk mencapai efisiensi dan efektivitas. Suatu kerja organisasi dapat diukur dengan banyak cara yang berbeda, salah satu cara yang umum banyak digunakan adalah dengan menggunakan patokan efisiensi dan efektivitas. TVRI Kalimantan Timur menggunakan sumberdaya yang ada guna mencapai hasil yang optimal juga mencapai keberhasilan dalam mencapai tujuan-tujuan yang telah ditentukan manajemen.

Manajer merupakan pribadi yang bertanggung jawab terhadap seluruh bagian dan kegiatan yang ada di organisasi, manajer memimpin beberapa unit pekerjaan untuk bergerak dan meraih tujuan.Menurut Lili Adi Wibowo dan Donni Juni Priansa (2017:41) : "Pada organisasi berstruktur tradisional, manajer sering dikelompokkan menjadi manajer puncak, manajer tingkat menegah, dan manajer lini pertama".

Pada media penyiaran implementasi tingkatan manajemen dalam organisasi TVRI Kalimantan Timur khususnya dalam Bidang 
Program yaitu siaran hiburan non berita tergambar dalam klasifikasi berikut :

a. Manajer lini pertama yaitu Kepala Seksi Produksi yang bertanggung jawab

merencanakan,

mengelola/memproduksi, menyiarkan dan mendokumentasikan acara di Bidang Program.

b. Manajer Tingkat Menengah yaitu Kepala Bidang Program dan Pengembangan Usaha, yang berperan sebagai penanggungjawab dan mengawasi setiap pelaksanaan produksi dan penyiaran serta mengevaluasi.

c. Manajer Puncak yaitu Kepala LPP TVRI Kalimantan Timur yang mempunyai tanggung jawab mengelola, merencanakan, mengorganisasi segala sumber daya, memimpin sesuai porsi tanggung jawabnya, serta mengevaluasi dan menetapkan kebijakan operasional produksi, penyiaran di TVRI Kaltim secara efektif, efesien dan akuntabel dan memancarluaskan siaran lokal dan nasional serta pengawasan pelaksanaannya sesuai dengan kebijakan Direksi.

Tingkat Manajemen dalam pelaksanaan produksi program Komedi Baelang TVRI Kalimantan Timur dapat diklasifikasikan lagi sebagai berikut :

1) Manajer Lini pertama yaitu Produser program Komedi Baelang yang bertanggungjawab terhadap perencanaan, pengorganisasian, pelaksanaan dan pengevaluasian program komedi Baelang, mulai dari praproduksi, produksi sampai paskaproduksi dan sampai program Komedi Baelang disiarkan.

2) Manajer Menengah yaitu Kepala Seksi Produksi yang bertanggung jawab terhadap kelancaran dan pengawasan produksi program Komedi Baelang. 
3) Manajemen Puncak yaitu Kepala Bidang Program dan Pengembangan Usaha yang bertanggung jawab penuh terhadap setiap produksi dan penyelenggaraan siaran dilingkup TVRI Kalimantan Timur.

\section{A.1. Analisa Pelaksanaan Fungsi Perencanaan}

Fungsi perencanaan di TVRI Kalimantan Timur dalam penyelenggaraan program Komedi Baeleng dilakukan oleh unsur-unsur pimpinan dilingkup struktural LPP TVRI Kalimantan Timur yang dipimpin oleh Kepala Stasiun TVRI Kalimantan timur sekaligus sebagai penanggungjawab seluruh operasional.Sebagai pelaksana di lapangan adalah Bidang Program dan Pengembangan Usaha yang dilaksanankan oleh Seksi Program.Secara teknis produksi dan penyiaran program Komedi Baelang dikelola oleh kelompok kerabat kerja dari berbagai profesi dibidang penyiaran televisi yang dipimpin oleh seorang Produser. Maka Produser selaku pemimpin kerabat kerja produksi program Komedi Bealang bertanggungtawab mulai dari perencanaan, produksi, paskaproduksi hingga penyiaran. Produser secara struktural bertanggungjawab kepada Kepala Seksi Program TVRI Kalimantan Timur.

Dalam perencanaan, ada aspek penting yang perlu diambil yaitu pembuatan keputusan (decision making) yaitu proses pengembangan dan penyeleksian sekumpulan kegiatan untuk memecahkan suatu masalah tertentu. Keputusankeputusan yang diambil dalam perencanaan program Komedi Baelang dilakukan dengan langkahlangkah penyusunan perencanaan, langkah-langkah penyusunan perencanaan menurut RoisArifin dan Helmi Muhammad (2016:30-31) "Pada dasarnya melalui empat 
tahapan sebagai berikut:

Menetapkan tujuan, Merumuskan

keadaan, Menentukan berbagai

alternative tindakan, dan

Mengadakan penilaian terhadap

berbagai Alternatif tindakan yang sudah dipilih".

Adapun langkah-langkah penyusunan perencanaan program Komedi Baelang di TVRI Kalimantan Timur :

\section{a) Menetapkan Tujuan.}

Penetapan tujuan mencakup pelaksanaan kegiatan praproduksi, produksi dan paskaproduksi serta jadwal penayangan program Komedi Baelang, pada tahap ini Produser menetapkan pengisi acara atau teater sekolah yang akan ditampilkan, berdasarkan permohonan dari sekolah atau masukan dan pengajuan dari Team Kreatif.

b) Merumuskan Keadaan.

Perumusan keadaan dalam perencanaan produksi program
Komedi Baelang dilakukan oleh Produser dengan melakukan analisis terhadap kebutuhan sumber daya manusia pengisi acara dan pelaksanaan kegiatan produksi program Komedi Baelang. Keterbatasan sound system dan peralatan band untuk mendukung program Komedi Baelang juga menjadi bagian pertimbangan dalam perumusan keadaan saat ini untuk perencanaan produksi Proram Komedi Baelang. Untuk mengatasi hal tersebut Produser mengajukan anggaran untuk meyewa sound system dan peralatan band yang disesuaikan dengan kemampuan TVRI Kaltim.

c) Menentukan berbagai alternatif tindakan.

Untuk mencapai suatu program televisi yang maksimal diperlukan suatu kondisi ideal menyangkut segala fasilitas dan kemampuan sumber daya 
manusia yang dimiliki oleh suatu lembaga penyiaran. Pelaksanaan produksi program Komedi Baelang diperhadapkan dengan beberapa kendala diantaranya peralatan sound system dan band yang tidak dimiliki oleh TVRI Kaltim.

\section{d) Mengadakan}

Penilaian Terhadap Berbagai Alternatif Tindakan Yang Sudah dipilih.

Tahap terakhir dalam proses perencanaan yaitu mengadakan penilaian terhadap berbagai alternative tindakan yang sudah dipilih, mengembangkan berbagai alternative kegiatan tersebut untuk mencapai tujuan, serta pemilihan alternative terbaik di antara berbagai alternative yang ada. Produser mengoptimalkan kemampuan yang ada dan diwujudkan dalam pencarian dan penjadwalan penampilan teater-teater sekolah yang bergantian menjadi pengisi acara program Komedi Baelang.
Perencanaan oleh Produser disampaikan kepada unsur pimpinan untuk melakukan koordinasi dan pengembangan kegiatan terkait kebijakan diinternal TVRI Kaltim.Pada praktiknya juga dilakukan koordinasi lintas bidang dimana Produser bersama dengan jajaran Seksi Teknik Studio melakukan koordinasi dengan Ka Bagian Umum terkait fasilitas umum pelaksanaan produksi. Produser juga berkoordinasi dengan Bagian Keuangan dalam melakukan koordinasi rencana anggaran dan biaya pelaksanaan produksi.

\section{A.2. Analisa Pelaksanaan Fungsi Pengorganisasian}

Pengorganisasian merupakan kegiatan dasar dari manajemen yang dilaksanakan untuk dan mengatur seluruh sumber-sumber yang dibutuhkan termasuk unsur manusia, sehingga pekerjaan dapat diselesaikan dengan sukses (George 
R. Terry 2014:73).Pengorganisasian dilakukan untuk menghimpun dan mengatur semua sumber-sumber yang diperlukan, termasuk kerabat kerja produksi program Komedi Baelang TVRI Kaltim, sehingga pekerjaan yang dikehendaki dapat dilaksanakan dengan berhasil. Dengan cara mengorganisir, orangorang dipersatukan dalam pelaksanaan tugas yang saling berkaitan. Seorang Produser harus mengetahui, kegiatan-kegiatan apa yang akan dilaksanakan, siapa yang membantu dan siapa yang dibantu, saluran-saluran komunikasi, pengelompokkan kerabat kerja, hubungan-hubungan antara kerabat kerja satu dengan kerabat kerja lainnya.Menurut Morissan (2013:150) pengorganisasian merupakan proses penyusunan struktur organisasi yang sesuai dengan tujuan organisasi, sumber daya yang dimiliki dan lingkungan yang melingkupinya.

\section{A.3. Analisa Pelaksanaan Fungsi Pengarahan. \\ George R.Terry \\ (2014:17)} mengatakan bahwa Actuating atau disebut juga 'gerakan aksi' mencakup kegiatan yang dilakukan seorang manager untuk mengawali dan melanjutkan kegiatan yang ditetapkan oleh unsur perencanaan dan pengorganisasian agar tujuantujuan dapat tercapai. Pelaksanaan produksi program Komedi Baelang dimulai sejak ditetapkannya bahwa program tersebut masuk dalam pola siaran TVRI Kalimantan Timur. George R.Terry dan Leslie W. Rue (2015:1) mengatakan “Manajemen adalah suatu proses atau kerangka kerja, yang melibatkan bimbingan atau pengarahan suatu kelompok orang-orang kearah tujuan-tujuan organisasi atau maksud-maksud yang nyata".

Kepala Stasiun TVRI Kaltim memberikan pengarahan secara garis besar pola acara TVRI Kaltim, Kepala bidang Program dan 
Pengembangan Usaha meneruskan kepada Kepala Seksi Program sebagai penanggung jawab operasional penyelenggaraan produksi program komedi Baelang. Kepala Seksi Program menunjuk salah satu staf untuk memproduksi dan menjadi Produser program Komedi Baelang.

Produser bertanggung jawab dalam merencanakan, mengorganisasikan, melaksanakan dan mengevaluasiserta mengen-dalikan penyelenggaraan produksi program Komedi Baelang. Keterlibatan banyak unsur lintas Bidang dilingkup TVRI Kalimantan Timur menjadikan pelaksanaan produksi lebih banyak berkutat pada perencanaan perangkat keras berupa infrastruktur dan peralatan penunjang serta perangkat lunak berupa manusia pengelola dan cara mengelolanya.

\section{A.4. Analisa Pelaksanaan Fungsi Pengevaluasian \\ atau Pengendalian}

Pelaksanaan

fungsi

monitoring dan evaluasi yang dilakukan pengelola program Komedi Baelang dilakukan dengan mengevaluasi hasil produksi yang telah diproduksi sebelumnya, memeriksa kesiapan peralatan dan kesiapan kerabat kerja produksi, memeriksa kesiapan pengisi acara dan seluruh pendukung program Komedi Baelang termasuk kesiapan penonton dari masing-masing sekolah yang akan hadir di studio TVRI Kaltim dan juga melakukan monitoring pada saat pelaksanaan produksi program Komedi Baelang berlangsung di studio 1 .

Fungsi utama dari pengevaluasian adalah ditujukan pada perbaikan dan peningkatan kualitas untuk mencapai tujuan, atau dengan kata lain adalah menilai dan memperbaiki faktor-faktor yang mempengaruhi pelaksanaan pekerjaan. Menurut Andi Fahruddin 
(2016:16-17) "Fungsi pengawasan (controlling) dan pengendalian, proses yang dilakukan untuk memastikan seluruh rangkaian kegiatan yang telah direncanakan, diorganisasikan dan diimplementasikan dapat berjalan sesuai dengan target yang diharapkan sekalipun berbagai perubahan terjadi dalam lingkungan dunia bisnis yang dihadapi".

\section{A.5. Analisis komunikasi dalam produksi Komedi Baelang TVRI Kalimantan Timur.}

Komunikasi adalah faktor yang sangat penting untuk dapat melaksanakan fungsi manajemen secara efektif. Menurut Wijaya dalam Yusuf Zainal Abidin (2015:32) mengatakan "Komunikasi dapat diartikan sebagai proses normal menyampaikan pesa dari komunikator ke komunikan melalui saluran atau media yang tepat sehingga menghasilkan efek yang diharapkan". Morissan (2013:163) mengatakan"Kerabat kerja membutuhkan informasi mengenai apa yang diharapkan atas diri mereka, rincian tugas (job description) secara tertulis dapat digunakan sebagai panduan umum bagi kerabat kerja, namun terkadang mereka membutuhkan informasi spesifik terkait dengan peran yang harus dilakukan dalam pekerjaan atau rencana saat ini".

Menurut Harold Lasswell dalam Hafied Cangara (2016:45-46) "Komunikasi merupakan suatu proses yang menjelaskan siapa (who), mengatakan apa (says what), dengan saluran apa (in which channel), kepada siapa (to whom), dengan akibat apa atau hasil apa / dampak (whit what effect)". Analisis 5 (lima) unsur komunikasi menurut Lasswell (1960) :

1) Who ? (siapa atau sumber).

TVRI Kalimantan Timur secara organisasi, merupakan sumber komunikator bagi pelaksanaan produksi program Komedi Belang dengan tujuan memberikan hiburan dan 
menyalurkan bakat seni teater bagi siswa SMA melalui teater sekolah. Dalam lingkup TVRI Kalimantan Timur pelaksanaan produksi tersebut dikerjakan oleh kerabat kerja yang dipimpin oleh seorang Pengarah Acara (PD) yang bertindak sebagai komunikator dalam proses produksi program Komedi Baelang.

2) Says What? (pesan).

Komedi Baelang oleh TVRI Kalimantan Timur yaitu ada pesan moral yang disampaikan dintaranya menghindari pergaulan bebas, melestarikan budaya, menjauhi narkoba dan minuman keras, dan sebagainya, selain hadir sebagai sarana pendidikan Komedi Baelang juga hadir sebagai sarana hiburan. Pada organisasi produksi atau kerabat kerja televisi maka pesan yang disampaikan pada saat produksi program Komedi Baelang dilakukan oleh Pengarah Acara kepada kerabat kerja produksi berupa instruksi kepada FD / Pengarah Lapangan, pengisi acara, dan seluruh kerabat kerja yang terlibat produksi.

3) In Which chanel ?(saluran atau media).

TVRI Kalimantan Timur melalui program Komedi Baelang menyampaikan pesan kepada penonton di studio secara langsung (tatap muka) dan kepada masyarakat penonton diluar studio secara tidak langsung melalui media televisi. Penyampaian pesan kepada kerabat kerja produksi Komedi Baelang dilakukan secara langsung /tatap muka dan secara tidak langsung melalui media elektronik handy talky.

4) To Whom ?(untuk siapa / penerima)

Program Komedi Baelang ditujukan kepada khalayak (audience) TVRI Kalimantan 
Timur sesuai dengan format program yaitu pelajar SLTA dan Mahasiswa. Dalam proses produksi dari praproduksi, produksi sampai paskaproduksi Produser dan Pengarah Acara juga melakukan komunikasi kepada 2 (dua) kelompok yaitu internal TVRI Kaltim dan eksternal yaitu pengisi acara.

5) With What Effect?(dampak)

Untuk pengisi acara penyampaian pesan secara lisan berdampak kepada hasil produksi sesuai dengan format program Komedi Baelang. Tujuan dari produksi program Komedi Baelang jelas untuk memberi hiburan dan pendidikan bagi pemirsa. Pengarah Acara selaku pemimpin produksi dalam menyampaikan setiap pesan harus jelas agar instruksi yang disampaikan dapat dilaksanakan sehingga hasil produksi sesuai dengan yang diinginkan.
Louis Forsdale dalam Yusuf Zainal Abidin (2015:33) “Komunikasi adalah proses memberikan signal menurut aturan tertentu sehingga suatu system dapat didirikan, dipelihara, dan diubah".Pada definisi ini, komunikasi juga dipandang sebagai proses, kata signal berupa verbal dan nonverbal yang mempunyai aturan tertentu, dengan adanya aturan ini, kerabat kerja program Komedi Baelang sebagai orang yang menerima signal dapat memahami maksud dari signal yang diterimanya, apabila Pengarah Acara sebagai orang yang mengirimkan signal menggunakan bahasa yang sama dengan orang yang menerima, penerima dapat memahami maksud dari signal tersebut.

Menurut Darwanto S. S. (1994:86-87) “Televisi sebagaimana bidang spesialisasi lainnya,memerlukan bahasa tersendiri dalam berkomunikasi, demikian halnya bahasa ukuran 
gambar serta gerakan kamera yang telah diformulasikan secara internasional, karena itu harus diketahui dan dipahami oleh mereka yang berkecimpung dalam dunia pertelevisian". Pengarah Acara dalam berkomunikasi harus menggunakan bahasa televisi yang sudah disepakati secara internasional dalam memberikan komando atau aba-aba kepada kerabat kerjanya.

Yusuf Zainal Abidin (2015:34) mengatakan: "Komunikasi adalah pertukaran pesan verbal ataupun nonverbal antara pengirim dan penerima pesan untuk mengubah tingkah laku, pengirim pesan dapat berupa seorang individu, kelompok, atau organisasi demikian pula penerima pesan". Pada proses produksi program Komedi Baelang TVRI Kalimantan Timur komunikasi dilakukan antarpribadi, komunikasi kelompok dan komunikasi organisasi.

\section{a) Komunikasi Antarpribadi.}

Berkenaan dengan pelaksanaan produksi program Komedi Baelamg jenis komunikasi antarpribadi ini sering dilakukan saat praproduksi, produksi sampai paskaproduksi, secara kelembagaan jenis komunikasi antarpribadi dilakukan oleh atasan dan bawahan. Saat pelaksanaan praproduksi, produksi hingga paskaproduksi program Komedi Baelang TVRI Kalimantan Timur komunikasi antarpribadi ini dilakukan dalam beberapa tahapan. Pertama scara structural Kepala TVRI Kalimantan Timur mengkomunikasikan kebijakan dan penyelenggaraan program Komedi Baelang kepada Kepala Bidang Program dan Pengembangan Usaha terkait pelaksanaan produksi. Kedua Kepala Bidang Program dan Pengembangan Usaha mengamanatkan kepada Kepala 
Seksi Program sebagai pihak bertanggung jawab dalam pelaksanannya. Ketiga

komunikasi antarpribadi dilakukan oleh Kepala Seksi Program dengan Produser, Kepala Seksi Program menunjuk Produser yang akan melaksanakan produksi program Komedi Baelang mulai dari praproduksi, produksi sampai paskaproduksi.Produser dalam pelaksanaa produksi, mulai dari peraproduksi, produksi sampai paskaproduksi juga terlibat komunikasi antarpribadi baik kepada setiap kerabat kerja dengn beragam profesi terutama dengan Pengarah Acara.

b) Komunikasi Kelompok.

Burgoon dan Ruffner dalam Iswadi Syahputra (2016:55) : "Memberi batasan komunikasi kelompok sebagai interaksi tatap muka dari tiga atau lebih individu guna memperoleh maksud atau tujuan yang dikehendaki seperti berbagi informasi, pemeliharaan diri atau pemecahan masalah sehingga semua anggota dapat menumbuhkan karakteristik pribadi anggota lainnya dengan akurat".Dalam proses produksi program Komedi Baelang pelaksanaan komunikasi kelompok didalam tahap praproduksi, produksi hingga tahap paskaproduksi dilaksanakan oleh team inti produksi yaitu Produser, Pengarah Acara dan Team Kreatif dan rapat internal dilingkup kerabat kerja produksi.

\section{c) Komunikasi Organisasi.}

Komunikasi dalam organisasi menurut Effendy dalam Yusuf Zainal Abidin (2015:65) “adalah komunikasi yang dilakukan pimpinan, baik dengan para karyawan maupun dengan khalayak yang ada kaitannya dengan organisasi, dalam rangka pembinaan kerja sama yang 
serasi untuk mencapai tujuan dan sasaran organisasi". Dalam proses produksi program Komedi Baelang Produser melakukan komunikasi internal dengan jajaran manajemen, dan juga melakukan komunikasi dengan kerabat kerja produksi serta melakukan komunikasi dengan sekolah-sekolah yang akan tampil di studio TVRI Kalimantan Timur.

\section{B. Analisis Strategi komunikasi Produser dalam mengelola program Komedi Baelang di LPP TVRI Kalimantan Timur.}

Strategi dalam komunikasi adalah cara mengatur pelaksanaan operasi komunikasi agar berhasil, dalam perencanaan strategi komunikasi perlu diketahui tujuan komunikasi, media yang paling tepat digunakan dan tingkat efektifitasnya. Strategi komunikasi pada hakikatnya adalah perencanaan (planning) dan manajemen untuk mencapai suatu tujuan.Untuk mencapai tujuan tersebut, strategi tidak hanya berfungsi sebagai peta jalan yang hanya menunjukkan arah, tetapi juga menunjukkan taktik operasional. Produser adalah orang yang bertanggung jawab mengubah ide / gagasan keatif kedalam konsep yang praktis dan dapat dijual, produser harus memastikan adanya dukungan keuangan bagi terlaksanannya produksi program Komedi Baelang serta mampu mengkomunikasikan seluruh proses produksi mulai dari praproduksi, produksi sampai dengan paskaproduksi termasuk melaksanakan penjadwalan. Produser Komedi Baelang juga ikut terlibat secara langsung dalam proses pengambilan keputusan setiap harinya, Produser harus mampu menterjemahkan dan mengkomunikasikan keinginan pimpinan dan juga audien melalui proses produksinya.

$\begin{array}{rrr}\text { Kunci } & \text { sukses } & \text { suatu } \\ \text { manajemen } & \text { penyiaran } & \text { adalah } \\ \text { komunikasi } & \text { yang lancar } & \text { antara }\end{array}$


berbagai bagian atau antara personel didalam satu bagian.Media penyiaran adalah lembaga yang hidup dalam bisnis komunikasi (Morissan, 2013:164).Kerabat kerja yang mengelola produksi Komedi Baelang terutama Produser harus memiliki komunikasi yang baik dan harus mampu menjadi komunikator yang baik.Komunikasi membantu Produser dan kerabat kerja melakukan pekerjaan dengan lebih baik, komunikasi yang baik menghasilkan aliran informasi yang lancar antara produser dengan kerabat kerja.Menurut Effendy dalam Yusuf Zinal Abidin (2015:115) “Strategi komunikasi merupakan panduan dari perencanaan komunikasi dan manajemen komunikasi untuk mencapai tujuan yang telah ditetapkan. Strategi komunikasi harus mampu menunjukkan operasionalnya secara praktis, artinya pendekatannya yang dugunakan dapat berbeda bergantung pada situasi dan kondisi".

Produser melakukan komunikasi terbuka dengan semua pihak yang terlibat dalam proses produksi program Komedi Baelang, pada tahap produksi jalinan komunikasi dibuka oleh Produser terhadap setiap masukan dari jajaran manajemen maupun staf pelaksana dalam kerabat kerja. Terkait penjaringan calon pengisi acara yang berkualitas maka Produser membuka jalur komunikasi dengan berbagai pihak diluar TVRI Kalimantan Timur, yaitu teater sekolah, dan teater kampus termasuk dengan team kreatif.Selain sekolah dan kampus juga dilakukan komunikasi kepada beberapa penggiat teater di Samarinda guna meminta masukan bahkan refrensi group teater mana yang dianggap layak untuk ditampiklan dalam program Komedi Baelang. Produser Komedi Baelang juga melakukan pengawasan langsung terhadap 
kemampuan pengisi acara saat pengisi acara dan penonton di melakukan gladi bersih di studio studio.

bersama team kreatif.

Menurut Morissan (2013:164)

Quinn dalam Yusuf Zainal "Mereka yang bekerja pada suatu Abidin (2015:116) menyatakan “Agar media penyiaran tidak dapat suatu strategi dapat efektif dilaksanakan dalam sebuah menahan atau menyimpan informasi program, harus mencakup beberapa hal, antara lain obyektif, memelihara inisiatif, konsentrasi, fleksibilitas, kepemimpinan yang memiliki komitmen dan terkoordinasi, kejujuran, dan keamanan".Strategi harus menentukan langkah dan menetapkan tindakan terhadap peristiwa, bukan bereaksi terhadap satu peristiwa.Selain itu, strategi juga mengamankan seluruh organisasi dan semua operasi penting organisasi. Produser Komedi Baelang disaat pelaksanaan produksi program Komedi Baelang melakukan pemberian instruksi kepada kerabat kerja yang bertugas secara garis besar terhadap rencana format produksi, juga memberikan instruksi secara garis besar kepada bisnis untuk diri mereka sendiri. Pada media penyiaran, menahan informasi dapat berakibat fatal bagi kesuksesan operasional.Lebih baik melakukan komunikasi yang berlebihan daripada mengalami kekurangan informasi.Lebih baik mendapatkan suatu informasi penting berkali-kali dari sumber yang berbeda-beda daripada mengalami satu kali kehilangan informasi". Dalam proses produksi Komedi Baelang mulai dari praproduksi, produksi sampai paskaproduksi Produser selalu memberi informasi dan melakukan komunikasi kepada manajmen TVRI Kaltim,kerabat kerja dan pengisi acara untuk mengingatkan tahapan produksi yang harus dilalui, misalnya tanggal / hari produksi, 
jam pelaksanaan produksi di Studio TVRI Kaltim dan juga mengingatkan tanggal, hari dan jam tayang saat disiarkan.

C. Analisis Kendala yang dihadapi kerabat kerja dalam pelaksanaan produksi di Studio (video taping) serta saat penyiaran program Komedi Baelang di LPP TVRI Kalimantan Timur

Menurut JB.Wahyudi (1994:4)" Siaran merupakan perpaduan antara kemampuan perangkat keras.Perangkat keras berupa studio dan perangkat penyiaran serta pemancar, sedangkan perangkat lunak berupa program (mata acara), sumberdaya manusia pengelola program, teknik dan administrasi".

Kendala terhadap perangkat keras adalah tidak adanya peralatan musik atau band serta sound system sehingga TVRI Kaltim harus menyewanya guna menunjang jalannya produksi Komedi Baelang. Dengan demikian biaya produksi program Komedi Baelang menjadi meningkat.

Kendala terhadap perangkat lunak meliputi :Sulitnya mencari pengisi acara yang berkualitas dan sesuai dengan format siaran TVRI Kalimantan Timur. Penjadwalan waktu produksi program Komedi Baelang, permasalahan yang dihadapi seperti benturan jadwal ujian semester oleh sekolah yang akan ditampilkan. Disisi lain pada saat-saat tertentu tidak mudah untuk mencari pengganti atau mendapatkan calon pengisi acara dalam hal ini teater sekolah yang telah siap tampil dan kualitas penampilan yang sesuai harapan.Kendala benturan jadwal produksi kadang terjadi, pada saat produksi dan siaran program Komedi Baelang dilakukan ternyata beberapa kerabat kerja sedang melakukan kegiatan produksi paket lain. Oleh Produser Komedi Baelang disiasati dengan melakukan penjadwalan ulang, kemudian 
segera dikomunikasikan kepada sebagai akibat bicara terlalu manajemen, kerabat kerja cepat.Menurut Hafied Cangara danseluruh pengisi acara.Kendala (2016:168-169) “Gangguan sematik komunikasi kerabat kerja dengan ialah gangguan komunikasi yang pengisi acara baik tim kreatif, musik disebabkan karena kesalahan pada pendukung, pemain utama dan bahasa yang digunakan, selain teater sekolah serta penonton kendala sematik juga terdapat distudio. Dalam konteks kendala psikologis".Sumber daya komunikasi, gangguan adalah segala manusia fungsional internal TVRI sesuatu yang menghalangi Kalimantan Timur yang tidak merata kelancaran komunikasi di sebut dalam hal kemampuan teknis gangguan (noise). Menurut Yusuf produksi dan pengalaman Zainal Abidin (2015:47) “Pada operasionalnya.

Menurut hakikatnya gangguan yang timbul JB.Wahyudi (1994:100) “Bekerja bukan berasal dari sumber atau didunia penyiaran tidak cukup saluran, melainkan dari hanya menguasai teori tetapi juga audiens/penerima karena manusia harus dipraktekkan, demikian juga sebagai komunikan memiliki berpengalaman dalam praktek tanpa kecendruangan untuk salah dilandasi teori juga kurang menafsirkan, tidak mampu mengingat dengan jelas yang diterimanya dari komunikator". Gangguan sematik telah menimbulkan persepsi yang keliru sehingga menimbulkan tanggapan yang salah, komunikator salah mengucapkan kata-kata atau istilah sempurna". Hidajanto Djamal dan Andi Fachruddin mengatakan : "Lembaga penyiaran dalam menjalankan fungsinya selalu mempunyai uraian tugas (job description) yang jelas dan spesifik untuk suatu fungsi tertentu". Tidak ada satu uraian tugas yang ganda, 
sehingga setiap unit organisasi akan menjalankan tugas yang tidak sama atau bersinggungan dengan tugas yang lain. Hal ini penting karena bekaitan dengan

pertanggungjawaban hasil tersebut.

Evaluasi program komedi Baelang, sebagai bahan koreksi untuk produksi yang akan datang. Menurut Hidajanto Djamal dan Andi Fachruddin (2013:138) “Proses evaluasi hasil produksi merupakan langkah yang harus dilakukan agar dapat diketahui kekurangan yang terdapat pada produksi itu, misalnya sudut pengambilan yang kurang akurat, pencahayaan muka pemain yang kurang pas sehingga masih terlalu gelap ketika shooting dilakukan siang hari". Lebih jauh Hidajanto Djamal dan Andi Fachruddin dalam bukunya mengatakan Proses evaluasi yang disebutkan ini sebetulnya berlangsung ketika shooting berjalan melalui monitor yang disediakan. Proses evaluasi ini dilakukan langsung oleh Produser ataupun Pengarah Acara, mengevaluasian setiap hasil produksi dan penayangan Program Baelang yang terdahulu sebagai sarana perbaikan mutu kemasan dan pemenuhan segmentasi pemirsa yang dituju. Jadwal tayang Komedi Baelang yang berubah, sehingga membingungkan penonton.Menurut Hidajanto Djamal dan Andi Fachruddin (2013:150) "Penayangan program acara televisi dapat disesuaikan dengan situasi seperti terjadinya satu keadaan darurat.Dalam keadaan darurat, maka jadwal program dapat dirubah, misalnya dengan istilah stop pres, breaking news, dan sejenisnya, sehingga beberapa program acara terjadwal sebelumnya dapat bergeser waktu tayangnya dan bahkan ditiadakan".

\section{KESIMPULAN}

Fungsi manajemen yang diterapkan olehKepala LPP TVRI Kalimantan Timur sebagai manajer puncak yang mempunyai tanggung 
jawab mengelola, merencanakan, mengorganisasi segala sumber daya, memimpin sesuai porsi tanggung jawabnya, serta mengevaluasi dan menetapkan kebijakan operasional produksi penyiaran di TVRI Kaltim. Program Komedi Baelang merupakan hasil kebijakan jajaran manajemen LPP TVRI Kaltim.Komunikasi adalah faktor yang sangat penting untuk dapat melaksanakan fungsi manajemen secara efektif. Komunikasi adalah cara yang digunakan pimpinan agar karyawan mengetahui atau menyadari tujuan dan rencana stasiun penyiaran agar mereka dapat berperan secara penuh tanggung jawab dan efektif untuk mencapai tujuan yang ditetapkan.

Strategi Produser Komedi Baelang dalam berkomunikasi adalah cara mengatur pelaksanaan produksi program Komedi Baelang. Produser melakukan komunikasi terbuka dengan semua pihak yang terlibat dalam proses produksi program Komedi Baelang. Strategi komunikasi Produser Komedi Baelang mampu menunjukkan operasionalnya secara praktis, artinya pendekatannya yang dugunakan dapat berbeda bergantung pada situasi dan kondisi. Kendala dalam proses produksi dan penyiran program Komedi Baelang TVRI Kaltim dapat dibagi menjadi dua bagian yaitu : kendala terhadap perangkat keras meliputi tidak adanya peralatan musik, peralatan sound system, dan kendala terhadap perangkat lunak meliputi kesulitan mencari pengisi acara, kendala penjadwalan waktu produksi, kendala penjadwalan anggota kerabat kerja, kendala komunikasi, ketersediaan SDM televisi, evaluasi belum sepenuhnya dilaksanankan, dan jadawal tayang Komedi Baelang yang berubah. 


\section{DAFTAR PUSTAKA}

Abidin, Yusuf Zainal. 2015. Manajemen Komunikasi:

Filosofi, Konsep, dan Aplikasi. Bandung: Pustaka Setia

Arifin, Rois dan Helmi Muhammad. 2016. Pengantar manajemen. Malanng : Empatdua

Baksin, Askurifai. 2013. Jurnalis Televisi : Teori dan Praktek.Bandung : Rosda Karya

Banjari, Atwar. 2015. Metode Penelitian Komunikasi : Prosedur, Tren, dan Etika.Bandung : Simbiosa Rekatama Media

Cangara Hafied. 2016. Pengantar ilmu Komunikasi. Jakarta : Raja Grafindo Persada.

Djamal, Hidajanto. 2017. TVPrograming: Sebagai Satu Kesisteman untuk Meraih Jumlah audiens secara Obtimal. Jakarta : Kencana

Djamal, Hidajanto dan Andi Fachruddin. 2013. Dasar-Dasar Penyiaran: Sejarah, Organisasi, Operasional, dan Regulasi. Jakarta: Kencana

Fachruddin, Andi. 2012. Dasar-Dasar produksi Televisi. Jakarta: Kencana Fachruddin, Andi. 2016. Manajemen Pertelevisian Modern.

Yogyakarta: Andi Offset

Fachruddin, Andi. 2015. Cara Kreatif Memproduksi Program Televisi.Yogyakarta: Andi Offset
Feriyanto, Andri dan Endang Shyta Tiana. 2015. Komunikasi Bisnis: Strategi Komunikasi dalam Mengelola Bisnis. Yogyakarta: Pustaka Baru

Hardjana, Andre. 2016. Komunikasi Organisasi: Strategi dan Kompetensi. Jakarta: Kompas.

Latif, Rusman dan Utud Yusiatie. 2015. Siaran Televisi Non Drma :Kreatif, Produksi, Public Relations, dan Iklan. Jakarta : Kencana.

Latif, Rusman dan Utud Yusiatie. 2017. Kreatif Siaran Televisi : Hard News, Soft news, Drama, Non-Drama. Jakarta : Kencana. Littlejohn, Stephen W. dan Karen A. Foss. 2009. Teori Komunikasi. Jakarta: Salemba Humanika

Morissan. 2013. Manajemen Media Penyiaran: Strategi Mengelola Radio $\mathcal{E}$ Televisi. Jakarta: Kencana

Mabruri, Anton. 2013. Manajemen Produksi Program Acara Televisi.Jakarta : Gramedia

Mulyana, Deddy. 2016. Ilmu Komunikasi: Suatu Pengantar. Bandung: Rosda

Mulyana, Deddy. 2013. Metodologi Penelitian Kualitatif. Bandung: Rosda

Naratama. 2013. Menjadi Sutradara Televisi :Dengan Singel Dan Multi Camera. Jakarta : Gramedia.

Nugroho, Sarwo. 2014. Teknik Dasar Videografi. Yogyakarta : Andi 
Panuju, Redi. 2017. Sistem Penyiaran

Indonesia : Kajian
Strukturalisme
Fungsional.Jakarta : Kencana

Pace, R. Wayne dan Don F. Faules.

2015. Komunikasi Organisasi: Strategi

Meningkatkan Kinerja

Perusahaan. Bandung : Rosda

Riswadi. 2009. Dasar-Dasar Penyiaran.

Jakarta : Graha Ilmu dan

Universitas Mercu Buana.

Romli, Khomsahrial. 2014.

Komunikasi Organisasi Lengkap.

Jakarta: Grasindo

Romli, Khomsahrial. 2016.

Komunikasi Massa. Jakarta: Grasindo

Ruliana, Poppy. 2014. Komunikasi

Organisasi : Teori dan Studi

Kasus. Jakarta: Rajawali Pers

Subroto, Darwanto Sastro. 1994.

Produksi Acara Televisi.

Yogyakarta : Duta Wacana

Universiti Press

Sugeng, Pujileksono. 2015. Metode

Penelitian Komunikasi

Kualitatif. Malang : Intras

Publising

Somad, Rismi dan Donni Juni

Priansa. 2014. Manajemen

Komunikasi: Mengembangkan

Bisnis Berorientasi Pelanggan.

Bandung: Alfabeta

Syahputra, Iswandi. 2016. Ilmu Komunikasi : Tradisi, Perspektif dan teori.Yogyakarta : Calpulis.

Wahyudi, J.B. 1994.Dasar-Dasar manajemen Penyiaran.Jakarta: Gramedia Pustaka.

\section{Internet :}

https://pakarkomunikasi.com/teoristrategi-komunikasi 